\title{
Pemimpin Ormas Keagamaan Sebagai Man of Communion dalam Situasi Konflik Menurut Paus Benediktus XV dan Yohanes XXIII
}

\author{
Alphonsus Tjatur Raharso \\ STFT Widya Sasana - Malang \\ atjaturr@gmail.com
}

\begin{abstract}
This article is written out of a concern about the religious leadership trend performed by some Islamic mass organization leaders during the first three month of 2017 in Jakarta which ended in horizontal conflicts and frictions based on religious and racial issues. Through the comparative method, this article would show the leadership role model of Catholic religious leaders, especially two Catholic popes during the World War I and II era, Pope Benedict XV and Pope John XXIII. While the world leaders were confronting to each other and created blocks to provoke wars, the both popes were present as fathers who loved and embraced all humankind across the nations. They placed themselves as the peace makers and invited the world to build peaceful co-babitation, which respected human right, as well as imposed justice for all humankind. The both popes were man of communion and sign of peace in amid of world conflicts. To be man of communion and sign of peace, the religious leaders need to restrain themselves to not be affected by the conflict issues that make them be sectarian, extremist, partisan, or partial. When there is a conflict because of any factors, the religious mass organization leaders might only observe whether there is a violation of human right, justice or bonum commune. If there is any, regardless from which race, religion, and class the victims are, they should fight for the justice, invoke human right, and generate bonum commune based on the legal law, by encouraging peace and harmony in the society.
\end{abstract}


[Artikel ini lahir dari sebuah keprihatinan mengenai model kepemimpinan religius yang ditampilkan oleh beberapa pemimpin ormas keagamaan Islam pada trimester pertama tahun 2017 di ibukota Jakarta dan berakhir pada gesekan dan konflik horisontal berdasarkan suku dan agama. Artikel ini ditulis dengan menggunakan metode komparatif, yakni dilakukan dengan menggali gaya kepemimpinan religius pemuka agama Katolik, khususnya dua orang Paus Gereja Katolik di masa Perang Dunia pertama dan kedua, yakni Benediktus XV dan Yohanes XXIII. Kedua Paus itu tampil sebagai bapa yang mencintai dan merangkul semua orang dan bangsa, menjadi juru-damai, serta mengajak para pemimpin bangsa untuk membangun cohabitation yang damai, yang menghormati hak dan martabat pribadi manusia, serta menegakkan keadilan bagi semua orang. Kedua Paus itu telah menjadi man of communion dan sign of peace yang efektif dalam situasi konflik mondial. Dari studi komparatif dapat ditemukan bahwa untuk bisa menjadi man of communion dan sign of peace dalam situasi konflik para pemimpin ormas keagamaan di Indonesia perlu menahan diri agar tidak terkooptasi dan menjadi sektarian, partisan atau parsialistik di hadapan dan di dalam kelompok yang dipimpinnya sendiri. Dalam konflik karena faktor apapun, para pemimpin ormas keagamaan hanya boleh mengawasi apakah terjadi pelanggaran terhadap hak asasi manusia, keadilan, atau bonum commune.]

Keyword: religious leadership, plural society, man of universal unity

\section{Pendahuluan}

Pada trimester pertama tahun 2017 Negara Kesatuan Republik Indonesia mengalami ujian berat mengenai kebhinekaannya. Kasus penistaan agama Islam oleh Basuki Tjahaja Purnama, Gubernur DKI Jakarta, telah memicu sentimen keagamaan yang selanjutnya menimbulkan gelombang demonstrasi di ibukota. Isu SARA dimunculkan sedemikian mencolok, sehingga menggantikan isu politik seputar pilkada DKI saat itu. Tampak juga gelombang demonstrasi itu di-backing-i, digelorakan, dan bahkan dipimpin langsung oleh beberapa pemimpin ormas keagamaan. 
Akibatnya, sikap dan tindakan yang tidak proporsional terhadap kasus penistaan agama beresiko menimbulkan keterpecahan bangsa atas dasar perbedaan agama dan ras. Sedangkan, politisasi sentimen keagamaan dan SARA mengandung resiko disintegrasi bangsa dan hancurnya sendi-sendi demokrasi negara, yang sudah lama dibangun atas dasar Pancasila dan UUD 1945. Toleransi antar umat beragama di Indonesia, yang sudah terkenal dan dipuji di seluruh dunia, dan bahkan dijadikan model toleransi bagi negara-negara lain, kini sungguh-sungguh mengalami ujian berat dan mulai dipersoalkan verifikasinya.

Situasi sosial-politik di ibukota NKRI saat itu sedemikian panasnya, sehingga pemerintah melalui Kementerian Agama memunculkan gagasan untuk melakukan standarisasi melalui sertifikasi bagi para pengajar dan pengkotbah agama Islam, agar dakwah mereka di masjid-masjid dan dalam pertemuan jemaah secara massal tidak hanya menyampaikan ajaran Islam dalam keutuhan dan kemurniannya, melainkan juga berisi pesan damai dan persaudaraan demi keutuhan dan kesatuan bangsa Indonesia yang bhinneka. Asumsi pemerintah ialah bahwa pemuka dan pendakwah agama memiliki posisi dan peran yang utama dan sentral dalam masyarakat agamis Indonesia. Kata-kata dan ajaran mereka didengarkan dengan penuh minat, dianggap dogma, dan dipatuhi oleh umatnya. Karena itu, mereka diharapkan memberikan dakwah agama yang menyuarakan kesejukan, serta perdamaian dan persaudaraan sejati. Meskipun wacana itu menimbulkan pro-kontra, Badan Koordinasi Mubaligh Indonesia (Bakormubin) mendukung upaya Kemenag, bahkan dengan membuat program kerja untuk mendidik sejuta mubalig penebar Islam damai. Program itu melibatkan Kementerian Agama, Kementerian Pertahanan, dan budayawan. Gagasan dibalik program itu ialah bahwa mubalig tidak boleh sekedar mendalami ilmu ke-Islaman, melainkan dalam konteks Indonesia mereka juga harus dibekali dengan pemahaman Pancasila serta UUD 1945. Melalui upaya itu diharapkan bahwa para mubalig akan menjadi penebar Islam yang damai, ikut aktif memecahkan masalah 
keagamaan di Indonesia, khususnya masalah pendangkalan sikap religius dan gejala islamofobia. ${ }^{1}$

Dengan latar belakang tersebut artikel ini mengkaji model kepemimpinan religius para pemimpin ormas keagamaan di NKRI yang plural. Dalam artikel ini dikupas bagaimana idealnya para pemimpin religius di Indonesia pada umumnya, dan khususnya dari agama Islam yang memiliki mayoritas penganut di bumi nusantara ini, menjalankan kepemimpinannya, sehingga dalam situasi yang rentan terhadap gesekan atau konflik sosial mereka mampu menjalankan kepemimpinan religius yang menyumbang secara efektif kondisi bangsa yang rukun, bersatu dan damai, demi pembangunan integral yang berkelanjutan.

Tulisan ini berangkat dari sebuah persoalan sederhana namun vital, yakni apa yang kurang dalam kepemimpinan religius beberapa pemimpin ormas keagamaan dalam gelombang demo tersebut, sehingga membuat mereka begitu emosional dan jatuh dalam ekstremisme, eksklusivisme, dan sektarianisme, yang semakin memanaskan gesekan sosial dan mengancam kohesi sosial yang sudah dibangun dengan susah-payah sejak lama? Dengan kata lain, apa yang perlu dilengkapi dalam kepemimpinan religius mereka, agar mampu menjadi figur rohaniawan yang sejuk dalam ajaran, santun dalam ujaran, merangkul dan mendamaikan semua golongan? Selain itu, apakah religius leadership itu merupakan prinsip-prinsip kepemimpinan umum yang diterapkan di bidang religius, ataukah ada unsur-unsur lain yang harus ditambahkan?

Pertanyaan itu dijawab dengan metode komparatif, yakni dengan menampilkan beberapa figur pembanding yang berasal dari lingkungan Gereja Katolik. Figur pembanding itu ialah para pemuka umat Katolik, khususnya Paus Benediktus XV dan Paus Yohanes XXIII. Metode komparatif dipakai, karena ada kemiripan situasi, yakni konflik politik dan sosial, meski skalanya berbeda. Gereja Katolik sendiri pernah memiliki pengalaman buruk dan pahit, di mana dari tahun 1096 hingga 1487 para pemimpinnya di Eropa (Paus, para Uskup dan imam) menebarkan pesan-

${ }^{1}$ Jawa Pos, 26 Februari 2017, 3. 
pesan kebencian, dan bahkan menyerukan di seluruh Gereja peperangan melawan ekspansi Islam, yang mencoba menguasai tanah suci dan sekaligus memasuki benua Eropa. Gereja Katolik ingin membangun kepemimpinan religius yang baru, melalui pembaruan mentalitas dan peraturan yang mengatur sikap dan tindakan kepemimpinan para imamnya. Metode komparatif ini sama sekali tidak bermaksud menunjukkan siapa dan mana yang lebih baik, melainkan apa yang dapat dipelajari dan diteladani dari kedua figur tersebut. Melalui metode komparatif tulisan ini menunjukkan keutamaan, kecerdasan, dan gaya kepemimpinan religius yang mestinya dianut oleh para pemimpin ormas keagamaan di tengah-tengah masyarakat Indonesia yang plural namun masih rentan terhadap gesekan sosial antar kelompok agama.

\section{Profil Singkat Paus Benediktus XV}

Paus Benediktus XV lahir di Genova (Italia Utara) pada tanggal 21 November 1854 dengan nama Giacomo Della Chiesa. Ia bergelar doktor dalam yurisprudensi sipil, dan kemudian menempuh studi di Kolese Capranica dan Universitas Gregoriana di Roma. Ia ditahbiskan sebagai imam pada tanggal 21 Desember 1878, dan langsung disekolahkan untuk menjadi diplomat Gereja Katolik. Dari 1883 hingga 1887 ia menjadi sekretaris Nuntius di Spanyol dan membantu Nuntius untuk menjadi penengah antara Jerman dan Spanyol dalam persoalan kepulauan Caroline. Keinginannya untuk menjadi Nuntius tidak tercapai, karena Paus Pius X mengangkatnya menjadi Uskup di Bologna pada tahun 1907. Pada Mei 1914 ia diangkat menjadi Kardinal. Melalui konklaf 3 September 1914 beliau terpilih menjadi pemimpin tertinggi Gereja Katolik sedunia dengan nama Benediktus XV, menggantikan Paus Pius X yang wafat pada 20 Agustus 1914. Keterpilihannya sangat mengejutkan, karena beliau sama sekali tidak dijagokan sebagai kandidat kuat (papabilis), mengingat baru tiga bulan diangkat menjadi Kardinal. Para peserta konklaf agaknya sungguh-sungguh sadar akan situasi kritis yang melanda Eropa, sehingga mereka sengaja memilih figur yang telah terbukti piawai di bidang 
diplomasi. ${ }^{2}$ Agar pelantikannya tidak kontras dengan situasi prihatin yang diakibatkan oleh perang yang baru saja pecah, Benediktus XV memilih Kapel Sistina sebagai tempat inkoronasinya, bukan Basilika Santo Petrus seperti biasanya. ${ }^{3}$ Setelah lebih dari tujuh tahun melayani sebagai Paus yang ke-258, ia wafat pada tanggal 22 Januari 1922.

\section{Sikap dan Tindakan Paus Benediktus XV selama Perang Dunia I}

Pelayanan Benediktus XV sangat diwarnai dengan keprihatinan mendalam dan konsisten atas perang dunia I. Beliau mengeluarkan serentetan kecaman dan kutukan atas peperangan, dengan menyebutnya sebagai "pemandangan yang mengerikan", "kutukan kemarahan Allah", "ladang pembantaian yang menghinakan Eropa", "dunia menjadi rumah sakit dan tumpukan tulang-belulang akibat perang", "tindakan bunuh diri Eropa”. ${ }^{4}$ Mudahnya menggunakan senjata dalam menyelesaikan masalah dianggap oleh Paus sebagai "tragedi paling kelam dari kebencian dan kebodohan manusia". ${ }^{5}$

Benediktus XV tidak hanya melancarkan kutukan atau kecaman verbal, melainkan secara aktif mengupayakan perdamaian. Beliau bersikap imparsial terhadap semua pihak yang berperang. Beliau sangat menghukum peperangan, namun tidak mau menjadi hakim yang menjatuhkan penilaian atau putusan mengenai motif-motif khusus yang dimiliki setiap negara ketika memulai peperangan. Paus ingin merangkul semua negara dan menjadi bapa rohani bagi semua pihak yang berperang. Sambil menyerukan agar perang segera diakhiri, beliau menginginkan perdamaian yang adil bagi semua, tanpa ada yang menang atau yang kalah, tanpa ada yang mendominasi atau yang ditundukkan, sehingga semua kekuatan bisa berdialog bersama. Karena itu, pada 1 Agustus 1917 Paus mengusulkan poin-poin perdamaian kepada semua negara yang terlibat

\footnotetext{
${ }^{2}$ John N.D. Kelly, Grande Dizionario Illustrato dei Papi, terj. A. Riccio (Casale Monferrato: Piemme,1995), 744.

${ }^{3}$ Erminio Lora dan Rita Simionati, eds., Enchiridion delle Encicliche, vol. 4, Pio Xe Benedetto XV (1903-1922) (Bologna: Dehoniano, 1998), 455.

${ }^{4}$ Lora dan Simionati, Enchiridion delle Encicliche, 456.

${ }^{5}$ Ibid. 456.
} 
perang, yakni (i) pengurangan senjata secara serempak dan pembentukan lembaga arbitrase yang mengikat semua pihak, (ii) kebebasan berlayar di laut dan pemilikan bersama wilayah perairan Eropa, (iii) tanggung-renteng pengeluaran akibat perang dan biaya pemulihan, (iv) saling mengembalikan teritori yang diduduki, dan pemberian jaminan bagi Belgia untuk mendapatkan kemerdekaannya secara penuh, (v) melakukan pengaturan bersama, berdasarkan inspirasi umum masyarakat Eropa mengenai masalah territorial yang harus didiskusikan antara Jerman, Perancis, Italia, dan Austria, (vi) pengamatan dan perlakuan yang adil bagi Armenia, negara-negara Balkan, dan teritori bekas Kerajaan Polandia. Usulan Paus tersebut memunculkan perdebatan di antara semua negara yang berperang, namun sama sekali tidak membawa dampak. Itu karena sebelumnya telah terjadi perjanjian rahasia di London pada 26 April 1915, malah atas usulan Italia, bahwa perwakilan Tahta Suci tidak akan dilibatkan dalam perjanjian perdamaian. Selain itu, beberapa pihak untuk sementara tidak ingin mengakhiri peperangan karena yakin akan memenangi peperangan. Meski demikian, Paus tetap kukuh dalam aksinya sebagai juru damai. Pada 24 Oktober 1917 beliau mengirim surat kepada Raja Austria, mengusulkan upaya "perdamaian melalui kompensasi tanpa humiliasi", untuk menghindarkan agitasi politik yang sulit diprediksi. ${ }^{6}$

Di samping upaya diplomatik yang gagal karena tak digubris itu, Vatikan melakukan karya karitatif dan aktivitas mitigasi dampak peperangan, melalui pertukaran korban luka, pengiriman bahan makanan dan bantuan bagi tawanan perang. Ribuan tawanan perang yang mengalami cacat dikembalikan ke tanah air mereka, demikian pula para tawanan yang merupakan ayah dari banyak anak, atau yang telah melewati 18 bulan di penjara. Karya karitatif kepausan membebaskan warga sipil yang ditawan, mengembalikan para pengungsi ke rumah tinggal mereka, menyediakan tempat penampungan di Swiss bagi lebih dari 30 ribu orang Perancis, Inggris, Belgia, dan Austria, memberikan hari libur pada hari Minggu bagi mereka yang dipenjara, dan sebagainya. Istana Kepausan

${ }^{6}$ Lora dan Simionati, Enchiridion delle Encicliche, 457-458. 
sendiri telah melayani 700 ribu permohonan informasi, memulangkan 40 ribu orang pengungsi, melakukan 500 ribu bantuan komunikasi dengan keluarga dari para pengungsi atau tawanan. Semua negara Eropa merasa berhutang budi kepada Paus, dan mengakui beliau sebagai guru peradaban dan persaudaraan insani. Dalam banyak kesempatan Paus menyampaikan keyakinannya bahwa perjanjian Versailles masih jauh dari sempurna untuk menjamin perdamaian yang pasti, dan menegaskan perlunya perdamaian yang langgeng, yang hanya bisa dijamin melalui pembaruan hidup religius. ${ }^{7}$

Dalam ensikliknya berjudul Pacem Dei Munus (1920), Paus mengingatkan kepada semua warga dunia dan negara-negara bahwa meskipun perang sudah berakhir hampir di semua tempat dan telah ditandatangani perjanjian-perjanjian perdamaian, namun benih-benih pertengkaran lama masih tetap bercokol dalam hati. Karena itu, beliau menyerukan agar diupayakan sekuat tenaga untuk membuang semua penyebab pertikaian, menegakkan keadilan bagi semua, dan bangsa-bangsa membangun kembali persatuan dan persaudaraan. ${ }^{8}$

\section{Profil Singkat Paus Yohanes XXIII}

Paus Yohanes XXIII lahir pada tanggal 25 November 1881 sebagai anak ketiga dari 13 bersaudara, dalam sebuah keluarga petani sederhana di desa Sotto il Monte (Bergamo). Ia diberi nama Angelo Giuseppe Roncalli. Ia ditahbiskan sebagai imam pada tanggal 10 Agustus 1904, dan kemudian sebagai Uskup pada tanggal 19 Maret 1925. Ia juga aktif dalam pelayanan diplomatik bagi Tahta Suci, yakni sebagai delegatus apostolik di Bulgaria (1931), di Turki dan Yunani (1934), sebagai Nuntius di Perancis (1945). Ia kemudian diangkat menjadi Kardinal pada tanggal 12 Januari 1953, dan tiga hari kemudian sebagai Batrik Venezia. Setelah dilakukan 12 kali pemungutan suara dalam tiga hari konklaf, pada tanggal 28 Oktober 1958 ia dipilih menjadi Paus Gereja Katolik yang ke-261 dengan gelar Yohanes XXIII.

\footnotetext{
${ }^{7}$ Ibid. 458-459.

${ }^{8}$ Ibid. 459.
} 
Banyak kalangan dalam Gereja Katolik mengira bahwa karena usianya yang sudah 77 tahun, Yohanes XXIII hanya akan melakukan aktivitas rutin dan administratif belaka. Ternyata ia mencetuskan dan melaksanakan gagasan-gagasan yang kemudian menjadi tonggak sejarah Gereja Katolik abad ke-20 dan seterusnya. Sekurang-kurangnya ada tiga proyek besar yang saling berkaitan, yakni Sinode Keuskupan Roma, Konsili Vatikan II, dan pembaruan UU universal Gereja.

Paus Yohanes XXIII sebenarnya tidak memiliki kaitan apa-apa dengan Perang Dunia I. Namun, beliau mengalami situasi perang itu, ketika masih sebagai imam muda berusia sekitar 30-an tahun. Beliau juga mengalami Perang Dunia II ketika usianya menjelang 60 tahun, dan aktif dalam pelayanan sebagai Uskup dan diplomat Vatikan. Kedua perang tersebut memberi dampak fisik, psikologis, dan spiritual bagi Angelo Roncalli (nama sebelum menjadi Paus). Kedua perang dunia itu telah menempa kepribadiannya, membangun refleksinya sebagai pemimpin umat, dan ikut menentukan visi-misinya sebagai pastor, terutama ketika bertugas sebagai delegatus apostolik, baik sebelum maupun selama perang dunia II, dan kemudian ketika menjadi Paus.

\section{Kepemimpinan Religius Paus Yohanes XXIII Selama Konflik Mondial Perang Dunia II}

Ketika pecah Perang Dunia I, Angelo Roncalli baru sepuluh tahun menjadi imam. Setelah Italia memutuskan untuk melibatkan diri dalam Perang Dunia I dan menyatakan secara resmi berperang melawan Austria, pada 24 Mei 1915 Romo Angelo dipanggil kembali untuk menjalankan dinas militer di Korps Medis di semua Rumah Sakit di Bergamo, dan kemudian sebagai kapelan militer. Tugas itu ia laksanakan sampai 10 Desember 1918. Wajib militer pernah beliau jalani sebelumnya, yakni ketika masih sebagai seorang seminaris teologan (November 1901November 1902), yang diakhirinya dengan pangkat sersan.

Kebiasaan menulis refleksi harian sejak di Seminari Menengah praktis terhenti selama Perang Dunia I. Kompilator catatan hariannya tidak

\footnotetext{
${ }^{9}$ Kelly, Grande Dirionario, 755.
} 
menemukan catatan pribadi apa pun dari Romo Angelo selama kurun waktu 1915-1918, dengan alasan "perang". Hanya ada satu catatan singkat tertanggal 23 Mei 1915, sehari menjelang keberangkatannya menuju dinas militer. Dalam catatan itu Romo Angelo bertanya dalam diri sendiri, apakah ia akan kembali lagi ke Bergamo ataukah Tuhan menetapkan hari terakhirnya di medan peperangan. Ia tidak tahu, namun yang ia cari hanyalah kehendak Allah dalam segala hal dan di setiap saat, serta bekerja untuk kemuliaan-Nya dengan pengorbanan diri yang total. ${ }^{10}$

Setelah Perang Dunia I berakhir dan selesai juga dinas militernya, sebelum memulai tugas baru sebagai pembimbing rohani bagi para frater di Seminari Tinggi Bergamo, dalam kesempatan retret pada akhir April 1919 Romo Angelo mengucap syukur kepada Tuhan bahwa selama empat tahun terjun di dunia yang sarat dengan penderitaan akibat perang ia diberi banyak kesempatan untuk melakukan kebaikan bagi sesama. Ia mengenang semua prajurit muda yang ia antarkan jiwanya memasuki alam baka. Kenangan akan jiwa-jiwa itu sungguh hidup dalam batinnya, dan bayangan bahwa mereka akan berdoa baginya sangat menghibur dan menyemangatinya. Selanjutnya, Romo Roncalli ingin menghidupkan kembali prinsip-prinsip hidup beriman dan hidup imamat yang sudah dianutnya sejak masa muda, yakni kemuliaan Allah, pengudusan diri, surga, Gereja, keselamatan jiwa manusia. Menurutnya, kontak dengan medan pertempuran telah mentransformasi prinsip-prinsip itu ke dalam aksi nyata, dan ia menghidupi prinsip-prinsip itu dalam kepemimpinan religiusnya. ${ }^{11}$

Pada tanggal 10 Juni 1940 Italia kembali mengumumkan secara resmi keterlibatannya dalam Perang Dunia II, berkoalisi dengan Jerman untuk berperang melawan Inggris dan Perancis. Pada malam harinya Mgr. Roncalli, yang sedang menjabat sebagai delegatus apostolik di Istambul, langsung menulis di buku hariannya: "Hari ini sangat menyedihkan buatku. Italia telah memaklumkan diri berperang melawan Inggris dan Perancis.

${ }^{10}$ John XXIII, Journal of a Soul, terj. Dorothy White (London: Geoffrey Chapman, 2000), 190.

${ }^{11}$ John XXIII, Journal of a Soul, 192. 
Perang selalu mengakibatkan kehancuran yang luar biasa. Bagi seorang kristiani yang mengimani Kristus dan Injil-Nya, perang sama dengan permusuhan dan kontradiksi. Mulai hari ini tanggung jawab dan kewajibanku menjadi lebih serius dan berat, untuk bertindak bijaksana, penuh pertimbangan dan kasih. Saya harus menjadi Uskup bagi semua orang, consul Dei, bapa, terang, dan pengharapan bagi semua. Sebagai manusia biasa saya berharap negara asalku Italia berhasil dan menang dalam Perang Dunia ini. Namun, sebagai seorang kristiani rahmat Allah mendorongku untuk membawa damai dan mengupayakan perdamaian bangsa-bangsa. Kodrat mendorongku untuk menginginkan kemenangan bagi negaraku. Namun, rahmat menginspirasiku untuk mengupayakan perdamaian". ${ }^{12}$ Roncalli sungguh-sungguh menghadapi situasi yang amat pelik saat itu, terutama dari aspek psikologis dan kemanusiaan. Lingkungan kerjanya di Kantor Delegasi Apostolik bercorak internasional, dan rekan-rekan kerjanya berasal dari berbagai kebangsaan: Perancis, Inggris, Italia, dan Jerman. Tanpa adanya perang saja beliau sudah merasa kesulitan untuk menjaga situasi plurinasional dan plurietnis yang seimbang dan penuh kekeluargaan di kantornya. Kini dengan adanya perang antar negara dan antar bangsa, komunitasnya menjadi terpecah. Nasionalisme yang tidak sehat telah menciptakan perpecahan, kebencian, dan dendam. ${ }^{13}$

Di kantor delegasi apostolik itu Roncalli memiliki seorang rekan kerja, biarawan berkebangsaan Perancis, mantan serdadu Perancis dalam Perang Dunia I. Ketika Italia menyatakan perang melawan Perancis, Roncalli langsung membayangkan bahwa rekan kerjanya itu akan merasa tidak nyaman dan tidak enak bekerja di kantornya. Perasaan itu muncul karena Italia dan Perancis sedang bermusuhan dan berperang. Karena itu, keesokan hari setelah Italia memaklumkan perang, pada pukul 8 pagi Roncalli berdiri di pintu masuk kantornya untuk menunggu kedatangan rekan kerjanya berkebangsaan Perancis itu. Ketika datang, Roncalli

\footnotetext{
12 R. Allegri, Il Papa Buono: La Storia di Giovanni XXIII (Milano: Oscar Mondadori, 2000), 182; A. Tjatur Raharso, Pernak-Pernik. Ajaran dan Keutamaan San Giovanni XXIII (Malang: Widya Sasana Publication, 2014), 154.

13 Allegri, Papa Buono, 182-83.
} 
membukakan pintu baginya, mempersilakan masuk, dan merangkulnya erat-erat, sambil membisikkan kata-kata: "Apa yang sedang terjadi di antara kedua negara kita, semoga tidak mengganggu kebersamaan kita. Kita adalah saudara di dalam Kristus, dan kita tetap saling mengasihi seperti biasanya". ${ }^{14}$

Pada suatu hari di Istambul ada seorang pejabat resmi berkebangsaan Inggris meninggal dunia. Ia seorang Katolik. Namun, tak seorang pun memberitahu Mgr. Roncalli, dengan alasan karena Inggris sedang bermusuhan dan berperang melawan Italia. Ketika Roncalli kemudian mengetahui hal itu, dia sangat kecewa dan marah terhadap para pegawainya, karena tidak mendapat kesempatan mendoakan dan memberkati jenazah pejabat itu. Beberapa minggu kemudian seorang pejabat berkebangsaan Italia meninggal dunia. Kali ini Roncalli langsung diberitahu. Namun, beliau berkata: "Saya akan berdoa bagi kesejahteraan arwah pejabat yang telah meninggal dunia itu. Namun, saya tidak akan datang dalam misa requiem, karena saya sebelumnya tidak datang dalam misa requiem bagi pejabat Inggris itu. Orang-orang mengira bahwa saya seorang nasionalis seperti kebanyakan orang pada saat ini. Itu keliru besar. Bagi seorang imam, semua orang adalah saudara dan saudari”. ${ }^{15}$

\section{Analisis Gaya Kepemimpinan Religius Kedua Paus dalam Situasi Konflik}

Bilamana Paus Benediktus XV dan Yohanes XXIII melakukan diplomasi aktif untuk menghentikan peperangan, serta menegakkan dan memelihara perdamaian dunia, hal itu mereka lakukan karena merasa diutus tidak hanya untuk memperhatikan umatnya sendiri, melainkan juga menggembalakan "domba-domba lain yang bukan dari kandang ini”" (Yoh 10:16). Mereka juga bertindak sebagai "guru dan pelindung kebenaran" di hadapan setiap hati nurani, dan utamanya di hadapan para penguasa atau petinggi negara-negara. Paus Benediktus XV mengatakan: "Ketika dari ketinggian martabat apostolik ini sekilas kami memandang kejadian-

${ }^{14}$ Allegri, Papa Buono, 183.

15 Allegri, Papa Buono, 183. 
kejadian di dunia, di hadapan kami langsung tersodor kondisi memprihatinkan masyarakat sipil. Kami sungguh-sungguh merasa sakit dan sedih. Bagaimana mungkin sebagai bapa semua orang, hati kami tidak merasa tercabik-cabik oleh pemandangan yang tergelar di Eropa, dan bersama Eropa seluruh dunia; sebuah pemandangan paling gelap dan paling menyedihkan sepanjang sejarah?"16 Patut kita garis bawahi ungkapan "bapa semua orang" (pater omnium communis) yang digunakan oleh Paus Benediktus XV.

Demikian juga, Yohanes XXIII menyebut dirinya sebagai Uskup bagi semua orang, consul Dei (penasihat dari Allah), bapa, terang, dan pengharapan bagi semua. Mengenai para pelarian politik, Yohanes XXIII merasakan kepahitan mendalam, karena terdorong oleh "perasaan sebagai bapa seluruh bangsa manusia" (paterna caritas) yang dinyalakan oleh Allah dalam hatinya. ${ }^{17}$ Dari kisah yang sudah dipaparkan di atas "menjadi Uskup bagi semua orang" berarti menjadikan semua orang saudara dan saudari, merangkul semua orang tanpa membedakan suku, bangsa, asal-usul negara, ras, dan golongan. Itu juga berarti melawan dan menolak nasionalisme yang sempit, radikal, dan tidak sehat. Dalam ensikliknya yang terkenal, Pacem in terris (11 April 1963), dalam rangka meredam perang dingin antara AS dan Uni Sovyet, "menjadi Uskup bagi semua orang" diungkapkan oleh Yohanes XXIII dengan mengajak dan mendesak semua pemimpin negara serta semua orang yang berkehendak baik untuk berpikir melampaui sekat-sekat, untuk melihat, mengakui, dan mengupayakan bersama nilai-nilai universal serta bonum commune universal.

Ada banyak butir pemikiran Yohanes XXIII mengenai prinsip-prinsip dan nilai-nilai universal itu. Pokok-pokok pikirannya tidak hanya berkaitan dengan kedua perang dunia yang sudah lewat, melainkan tetap relevan

\footnotetext{
${ }^{16}$ Benediktus XV, Ensiklik Ad Beatissimi Apostolorum Principis, 1 November 1914, dalam Enchiridion delle Encicliche, vol. 4, Pio X e Benedetto XV (1903-1922), ed. Erminio Lora dan Rita Simionati (Bologna: Dehoniano, 1998), 467.

${ }^{17}$ Yohanes XXIII, Litt. Enc. Pacem in Terris, 11 April 1963, dalam Enchiridion delle Encicliche, Vol. 7, Giovanni XXIII e Paolo VI, ed. Erminio Lora dan Rita Simionati (Bologna: Dehoniano, 1994), 433.
} 
untuk mengantisipasi setiap potensi konflik atau peperangan di kemudian hari, entah berskala kecil ataupun besar, baik konflik internal dalam sebuah negara maupun konflik internasional antar negara. Dalam tulisan ini kita angkat secara ringkas beberapa pokok pikiran terpenting.

Pertama, dunia jelas sangat membutuhkan tatanan. Namun tatanan itu tidak bersumber dari adu kekuatan manusia, apalagi dengan menggunakan senjata, melainkan berdasarkan tatanan yang ditetapkan Allah dan sudah tertanam dalam harkat dan martabat pribadi manusia. Konflik dan peperangan merupakan buah deviasi ketika kehidupan bersama bangsa manusia ditentukan oleh kekuatan yang dibangun oleh masing-masing negara dan terkontaminasi oleh unsur-unsur irasional. Tidaklah cukup bagi negara-negara untuk sekadar menciptakan co-exsistence (ada berdampingan), melainkan hidup bersama-sama dan bekerjasama saling membangun (convictus, co-babitation). Co-babitation yang tertata dan membangun harus didasarkan pada prinsip bahwa setiap individu adalah persona yang rasional dan berkehendak bebas, subjek hak dan kewajiban yang universal, yang tidak bisa dilanggar atau dipisahkan dari pribadinya. Selanjutnya, Yohanes XXIII menjelaskan secara rinci hak dan kewajiban itu, antara lain hak untuk hidup dan membangun kehidupan yang bermartabat, hak atas pendidikan, hak untuk beribadah kepada Allah berdasarkan keyakinan hati nurani, baik secara privat maupun di ruang publik, hak atas kebebasan memilih status kehidupan, hak atas kebebasan berinisiatif di bidang ekonomi dan pekerjaan, hak untuk berkumpul dan membentuk asosiasi, hak untuk bermigrasi, dan hak untuk berpartisipasi dalam kehidupan publik demi mewujudkan bonum commune (kebaikan umum). ${ }^{18}$

Kedua, co-babitation antara bangsa-bangsa yang tertata menuntut adanya otoritas public, yang menjamin keberlangsungan tatanan itu hingga semua elemen masyarakat dapat bersama-sama mewujudkan bonum commune. Namun, Yohanes XXIII menegaskan bahwa otoritas publik bukanlah organ yang bebas dari kontrol dan pengawasan. Otoritas publik harus menjalankan tugas dan kewenangannya berdasarkan rasionalitas dan

${ }^{18}$ Yohanes XXIII, Pacem in Terris, 384-393. 
moralitas. Otoritas duniawi hanya dapat memerintahkan sesuatu secara moral kepada bawahan hanya jika mencerminkan dan berpartisipasi pada otoritas Allah. Dengan demikian, ketaatan warga kepada otoritas publik bukan lagi merupakan ketaatan bawahan terhadap atasan, ketaatan man-toman belaka, melainkan ungkapan ketaatan kepada Allah Pencipta. Karena itu pula, jika perintah atau hukum yang diciptakan oleh otoritas publik bertentangan dengan kehendak Tuhan dan tatanan-Nya, maka perintah atau hukum itu kehilangan daya wajibnya di dalam hati nurani para warganya. ${ }^{19}$

Ketiga, dalam mempromosikan dan mewujudkan bonum commune hendaknya diperhitungkan keragaman etnis dalam setiap negara. Dalam konteks keragaman itu, setiap warga memiliki hak untuk berpartisipasi dalam mewujudkan bonum commune masing-masing dalam tingkat yang berbeda berdasarkan kondisi, tugas, dan jasanya dalam komunitas itu. Selanjutnya, otoritas publik menjamin dan mempromosikan hak setiap orang demi kebaikan semua orang, tanpa preferensi atau privilege apa pun terhadap warga atau kelompok tertentu. Demi keadilan dan cinta-kasih yang lebih tinggi, otoritas publik memberikan perhatian khusus kepada anggota masyarakat yang paling lemah, yang berada dalam kondisi inferior dalam mewujudkan hak-haknya dan dalam mengupayakan kebutuhankebutuhannya yang legitim. ${ }^{20}$

Keempat, sudah menjadi kenyataan bahwa ada perbedaan atau kesenjangan resources antara negara yang satu dengan yang lain. Ada negara yang memiliki segala-galanya, baik kekayaan alam maupun modal untuk mengolahnya. Namun, ada juga negara yang hanya memiliki kekayaan alam, namun minim modal. Kenyataan itu seharusnya tidak membuat masing-masing negara menutup diri dan merasa cukup dengan diri sendiri, melainkan membangun kerjasama yang memudahkan sirkulasi modal, kekayaan, dan tenaga manusia. Modal atau kapital seharusnya disirkulasi ke tempat-tempat dimana berkumpul tenaga kerja, bukan sebaliknya

\footnotetext{
${ }^{19}$ Ibid. 403-407.

${ }^{20}$ Yohanes XXIII, Pacem in Terris, 407-409.
} 
tenaga kerja berlari-lari menuju tempat menumpuknya kapital, sehingga tenaga kerja menjadi tercerabut dari tanah airnya dan dari komunitasnya menuju tempat yang asing baginya. ${ }^{21}$

Kelima, perdamaian dunia sebenarnya tidak bisa dan tidak boleh didasarkan pada keseimbangan dalam kepemilikan senjata di antara negara-negara. Ketika negara yang satu mulai memiliki senjata, maka negara-negara yang lain merasa berhak juga untuk mempersenjatai diri demi keadilan dan keseimbangan. Yang kemudian terjadi ialah persaingan dalam pemilikan persenjataan, dan sekaligus perlombaan untuk mempercanggih persenjataan dan sistem keamanan masing-masing negara. Sekalipun seandainya negara-negara itu menyatakan akan bertanggung-jawab memperbaiki kerusakan yang diakibatkan oleh persenjataannya, dan seandainya berjanji tidak akan mengumumkan perang, umat manusia tetaplah hidup dalam ketakutan dan kekhawatiran mendalam bahwa konflik terpanas akhirnya mengantar negara-negara untuk saling berperang dengan menggunakan senjata tercanggihnya. Jadi, Paus menegaskan bahwa perdamaian yang sejati tidak mungkin lahir dari keseimbangan sistem persenjataan antar negara. Dengan kata lain, demi keadilan, kebijaksanaan dan demi kemanusiaan Paus Yohanes XXIII menyerukan agar semua pemerintah negara tidak mudah lari kepada penggunaan senjata untuk menyelesaikan konflik internasional secara bertahap bersama-sama mengurangi persenjataan, dan menghentikan sama sekali percobaan atau pemilikan senjata nuklir. ${ }^{22}$

Kedua Paus tersebut, seperti banyak Paus lainnya, menunjukkan sikap kebapaan yang merangkul semua orang dari berbagai golongan, suku, agama, kebangsaan, dan aliran politik. Dalam konflik dan peperangan para Paus tidak hanya memikirkan dan membela hak-hak umat Katolik atau Gereja Katolik saja, melainkan memikirkan kebaikan umum semua orang dan perdamaian dunia. Mereka tidak ikut menjadi sektarian atau partisan, tidak memihak atau menggabungkan diri pada satu kelompok atau aliran

21 Ibid. 431-433.

${ }^{22}$ Yohanes XXIII, Pacem in Terris, 435-437. 
untuk memerangi aliran atau kelompok lain. Para Paus tidak mau terkooptasi atau memihak pada satu kelompok atau aliran tertentu dari pihak-pihak yang bertikai, melainkan ingin berdiri di tengah-tengah untuk merangkul semua pihak dan mengajak semua mengupayakan bersamasama perdamaian dan persaudaraan universal. Seruan dan himbauan moral mereka didasarkan pada nilai-nilai universal, yang bisa diterima oleh akal sehat dan oleh semua orang yang berkehendak baik. Dalam kesemuanya itu, kedua Paus telah menjadi man of communion (insan persekutuan) dan sekaligus sign of peace bagi seluruh warga dunia.

\section{Man of Communion: Makna dan Implikasi Etis bagi Kempemimpinan Religius}

Gaya kepemimpinan religius yang ditampilkan kedua Paus itu sebenarnya bukanlah kekhasan pribadi mereka berdua saja. Sebagai pemimpin tertinggi mereka telah menjadi contoh yang terbaik dan paling menonjol. Namun, kepemimpinan religius seperti itu juga dijalankan oleh para pemuka umat Katolik yang tersebar di seluruh dunia, yakni Uskup, imam, dan diakon di tempat masing-masing. Mereka telah dibentuk oleh sekumpulan kode etik yang ditetapkan dalam UU Gereja Katolik, yang terkenal dengan nama Kitab Hukum Kanonik (disingkat KHK). Norma pertama menetapkan cara hidup para imam Katolik di tengah-tengah masyarakat majemuk: "Para klerikus hendaknya selalu memupuk damai dan kerukunan sekuat tenaga berdasarkan keadilan yang harus dipelihara di antara sesama manusia" (KHK 1983, kan. 287, \1). ${ }^{23}$ Kata "sesama manusia" menunjukkan bahwa upaya membangun relasi yang damai dan rukun tidak hanya dibatasi secara internal pada umat Katolik saja, melainkan dengan semua orang dari semua golongan SARA. Norma tersebut merumuskan secara positif apa yang ditetapkan secara negatif

\footnotetext{
23 Yang dimaksud dengan klerikus (clerics) ialah pemimpin umat Katolik yang telah ditahbiskan menjadi diakon, imam, atau Uskup. KHK adalah singkatan dari Kitab Hukum Kanonik (Latin: Codex Iuris Canonici), sebuah kitab UU yang dikeluarkan oleh kuasa legislatif tertinggi Gereja Katolik dan diberlakukan di seluruh Gereja Katolik di dunia. Yang berlaku sekarang ialah yang diundangkan pada tanggal 25 Januari 1983 (KHK 1983), untuk menggantikan yang dikeluarkan pada tahun 1917 (KHK 1917). Pasal-pasal dalam UU ini disebut dengan istilah "kanon" (disingkat kan.).
} 
oleh UU lama: "Para klerikus juga dilarang berpartisipasi dengan cara apapun dalam perang saudara atau huru-hara publik" (KHK 1917, kan. 141). ${ }^{24}$

Norma kan. 287, $\$ 1$ di atas menggandengkan damai dan kerukunan dengan keadilan. Hal ini selaras dengan ajaran konstan Gereja Katolik bahwa tidak ada kedamaian dan kerukunan bila prinsip-prinsip keadilan dilupakan atau dilanggar. Kedamaian dan kerukunan ada dan langgeng jika didasarkan pada keadilan. Tanpa keadilan, kedamaian dan kerukunan hanyalah semu atau palsu. Karena itu, keadilan selalu bisa dituntut dan diperjuangkan oleh setiap orang, termasuk para pemuka agama atau pemimpin ormas keagamaan, demi mewujudkan kedamaian dan kerukunan yang autentik. Namun, perjuangan menuntut keadilan harus tetap menjunjung tinggi dan memelihara kedamaian dan kerukunan di antara semua warga masyarakat. Karena itu pula, dengan tetap menjaga perdamaian dan kerukunan di antara semua orang, melalui aktivitas para imam dan seluruh umat Gereja berwenang untuk selalu dan di mana saja memaklumkan prinsip-prinsip moral, juga yang menyangkut tata kemasyarakatan, dan memberi penilaian tentang segala hal ikhwal manusiawi, sejauh hak-hak asasi manusia atau keselamatan jiwa-jiwa menuntutnya (kan. $747, \$ 2)$.

Norma kan. 287, \1 berinspirasi pada ajaran para Uskup peserta Konsili Vatikan II (1963-1965), yang menegaskan bahwa tugas imam Katolik tidak hanya dibatasi pada pelayanan individual umat di lingkungan Gereja katolik saja, melainkan mencakup semua orang. ${ }^{25}$ Peran dan tugas imam ialah menjadi figur publik yang merepresentasi Gereja. Jadi, sebagai pemimpin Gereja setiap imam mengemban visi dan misi Gereja: "Sebagaimana Allah Bapa itu adalah sumber segala sesuatu, kita semua

\footnotetext{
${ }^{24}$ John P. Beal, James A. Coriden, dan Thomas J. Green, eds., New Commentary on the Code of Canon Law (New York: Paulist Press, 2000), 379. Dalam bahasa Latin norma lama itu berbunyi: "Neve intestinis bellis et ordinis publici perturbationibus opem quoquo modo ferant (clerici)". ${ }^{25}$ Konsili Vatikan II, Dekret Presbyterorum Ordinis, 7 Desember 1965, dalam Dokumen Konsili Vatikan II, terj. Robertus Hardawiryana (Jakarta: Dokpen KWI / Obor, 1998), 472.
} 
dipanggil untuk menjadi saudara. Karena bersama-sama mengemban panggilan manusiawi dan ilahi yang sama, kita dapat dan memang wajib juga bekerja sama tanpa kekerasan, tanpa tipu muslihat, untuk membangun dunia dalam damai yang sejati. ${ }^{26}$ Sinode Para Uskup pada tahun 1971 tentang keadilan di dunia juga menegaskan bahwa Gereja menerima dari Yesus Kristus misi untuk mewartakan pesan Injil, persaudaraan universal, dan tuntutan keadilan di dunia. Karena itu, Gereja memiliki hak dan kewajiban untuk mewartakan keadilan sosial, baik di level nasional maupun internasional, dan untuk menggugat situasi yang tidak adil, sejauh dituntut oleh hak-hak fundamental manusia dan keselamatannya. $^{27}$

Selanjutnya, kan. 287, $\$ 2$ menetapkan bahwa para klerikus dilarang mengambil bagian aktif dalam partai-partai politik, kecuali jika menurut penilaian otoritas gerejawi yang berwenang hal itu perlu untuk melindungi hak-hak Gereja atau memajukan kebaikan umum. Norma ini tidak ada dalam UU yang lama. Meski demikian, sesudah PD I sebenarnya ada banyak dekret telah dikeluarkan oleh Vatikan untuk melarang para klerikus melakukan aktivitas politik. ${ }^{28}$ Karena norma tersebut berisi larangan, maka penafsiran atas norma itu tidak boleh longgar atau luas, melainkan harus dilakukan secara sempit dan ketat (bdk. kan. 18). Dengan demikian, sekadar menjadi penasihat atau anggota dewan pertimbangan partai atau pemerintah tidak dilarang. ${ }^{29}$

Memang bisa dibayangkan betapa umat akan kehilangan orientasi dan terpecah belah, bilamana imam-imamnya terlibat aktif dalam partai-partai politik. Ini mengingat adanya banyak partai dan faksi-faksi politik berdasarkan ideologi yang berbeda-beda, yang saling bersaing merebut

\footnotetext{
${ }^{26}$ Konsili Vatikan II, Konstitusi Pastoral Gaudium et spes, 7 Desember 1965, dalam Dokumen Konsili Vatikan II, terj. Robertus Hardawiryana (Jakarta: Dokpen KWI / Obor, 1998), 636.

27 Sinode Para Uskup, Convenientes ex Universo, 30 November 1971, dalam Enchiridion Vaticanum, vol. 4, Documenti Ufficiali della Santa Sede 1971-1973, ed. Erminio Lora (Bologna: Dehoniano, 1978), 819.

${ }^{28}$ Beal, Coriden, dan Green, New Commentary, 380.

${ }^{29}$ Ibid. 376.
} 
kekuasaan dan menjalankan pengaruh di antara warga masyarakat agar mereka menyambut ideologinya serta membangun negara berdasarkan ideologi itu. Kalaupun para imam Katolik terjun hanya di satu partai politik, itupun sudah menciptakan kesan bahwa partai itulah yang didukung oleh Gereja Katolik, sehingga menempatkan Gereja Katolik beroposisi terhadap partai-partai lain. Akhirnya, Gereja malah terkooptasi dan terkungkung dalam ideologi politis atau sistem politik tertentu, lalu kehilangan kebebasannya untuk bergerak dan bekerja sama dengan semua orang dari berbagai ideologi demi kebaikan semua warga. Jangan sampai terjadi bahwa seorang imam Katolik, barangkali karena terdorong oleh panggilan hati nuraninya, terjun ke dunia politik dengan maksud untuk menyehatkan kehidupan politik nasional, dengan cara memerangi ketidakadilan, eksploitasi dan berbagai bentuk penjajahan, malah terjerumus bersama partai itu ke dalam bentuk eksploitasi yang baru dan lebih buruk terhadap kaum miskin, atau terlibat dalam praktik korupsi partai itu. ${ }^{30}$

Ketentuan tersebut di atas juga berinspirasi secara langsung pada ajaran Konsili Vatikan II, bahwa dalam membangun kehidupan iman jemaat para imam tidak pernah bekerja demi suatu ideologi atau bagi suatu partai. $^{31}$ Sinode Para Uskup di Roma pada tahun 1971 menegaskan kembali ajaran Konsili tersebut dengan nada sedikit lain: "Bilamana ada bermacam-macam pilihan politik, sosial, atau ekonomi yang legitim, para imam Katolik memiliki hak untuk menentukan posisi dan pilihannya, seperti setiap warga negara yang lain. Namun, mengingat pilihan-pilihan politik pada dasarnya bersifat sementara (contingent) dan tidak pernah menafsirkan atau mencerminkan Injil secara tetap dan utuh, maka setiap imam Katolik harus menjadi saksi mengenai "dunia yang akan datang", dan karenanya harus menjaga jarak dari jabatan atau keterlibatan politik. Agar tetap bisa menjadi tanda dan alat pembangun kesatuan yang efektif,

\footnotetext{
${ }^{30}$ Jorge De Otaduy, Exegetical Commentary on the Code of Canon Law, Vol. II/1, ed. Angel Marzoa, Jorge Miras, dan Rafael Rodríguez-Ocaña (Canada / Chicago: Wilson\&Lafleur / Midwest Theological Forum, 2004), 385-87.

${ }^{31}$ Konsili Vatikan II, Presbyterorum Ordinis, 473.
} 
serta dapat mewartakan Injil dalam kepenuhannya, para imam dapat diwajibkan untuk berpantang dan menjauhkan diri dari bidang politik". ${ }^{32}$ Meski demikian, norma kan. 287, \$2 sama sekali tidak bermaksud menghapus hak-hak politik para imam. Mereka tetap memiliki secara utuh dan penuh hak atas pendapat politik pribadi dan mewujudkan hak itu dalam pemberian suara (coblosan) menurut hati nuraninya sendiri.

Sebelumnya, dalam norma kan. 285, §3 para klerikus dilarang menerima jabatan-jabatan publik yang mengandung pelaksanaan otoritas sipil. Otoritas sipil itu mencakup kuasa legislatif, administratif, dan yudikatif, misalnya anggota DPR, presiden, menteri, gubernur, walikota, camat, hakim negara, dan sebagainya. Yang dilarang tidak hanya "menerima jabatan publik", melainkan juga "mencalonkan diri untuk suatu jabatan publik". ${ }^{33}$ Berkaitan dengan hal ini, secara lebih jelas dan konkret Sinode Para Uskup 1971 mengajarkan bahwa mengemban fungsi pemimpin atau secara aktif menjadi sayap militer bagi kepentingan sebuah partai politik harus dijauhkan dari kehidupan imam Katolik, kecuali dalam kasus-kasus kekecualian hal itu sungguh-sungguh dituntut demi kebaikan umum, namun selalu dengan persetujuan Uskup, setelah Uskup itu berkonsultasi dengan Dewan Imam, dan jika perlu dengan Konferensi Para Uskup. ${ }^{34}$

Kembali ditekankan dalam norma-norma itu bahwa selaku figur publik dan pemimpin jemaat para imam Katolik harus menjadi representasi Gereja, yang mengemban visi dan misi Gereja secara utuh. Apakah visi dan misi Gereja Katolik itu? Para Bapa Konsili Vatikan II mengajarkan bahwa misi khusus yang dipercayakan oleh Yesus Kristus kepada Gereja tidak terletak di bidang politik, ekonomi atau sosial, melainkan di bidang religi. Selanjutnya, berdasarkan misi dan hakikatnya

\footnotetext{
32 Sinode Para Uskup, Ultimis Temporibus, 30 November 1971, dalam Enchiridion Vaticanum, Vol. 4, Documenti Ufficiali della Santa Sede 1971-1973, ed. Erminio Lora (Bologna: Dehoniano, 1978), 781.

33 Beal, Coriden, dan Green, New Commentary, 376; Tomas Rincón Peréz, Code of Canon Law Annotated, ed. Ernest Caparros, Michel Thériault, dan Jean Thorn (Montréal: Wilson\&Lafleur, 1993), 236-370.

34 Sinode Para Uskup, Ultimis Temporibus, 781.
} 
Gereja tidak terikat pada bentuk khas kebudayaan manusiawi atau sistem politik, sistem ekonomi atau sosial manapun juga. Dengan kata lain, Gereja tidak mengidentikkan diri dan tidak diidentikkan dengan partai politik mana pun, melainkan bekerja sama dengan sistem politik dan sistem pemerintahan mana pun yang sah, demi kebaikan umum, persaudaraan dan persatuan bangsa manusia. Karena itu, berdasarkan sifat universalnya Gereja dapat menjadi tali pengikat yang sangat erat antar berbagai masyarakat dan bangsa manusia, asal mereka mempercayai Gereja, dan sungguh-sungguh mengakui kebebasannya yang sejati untuk menunaikan misinya itu. ${ }^{35}$

Selain itu, larangan untuk mengambil bagian secara aktif dalam partai politik dimaksudkan agar para imam tidak mengambil alih apa yang menjadi peran dan tugas khas kaum awam di dalam Gereja dan di tengahtengah masyarakat. Sebagai anggota penuh Gereja dan masyarakat sipil, kaum awam memiliki tugas khas mengelola bidang-bidang duniawi (ilmu pengetahuan dan teknologi, politik, ekonomi, sosial, kebudayaan, pertahanan, dan keamanan) dalam terang ajaran Injil dan ajaran Gereja, serta digerakkan oleh cinta-kasih kristiani. Di bidang-bidang itulah kaum awam Katolik hadir dan berkiprah secara langsung dan konkret. ${ }^{36}$ Ketentuan itu juga didukung oleh norma kanonik lain, bahwa para klerikus hendaknya mengakui dan memajukan misi yang dilaksanakan awam dalam Gereja dan dunia menurut peranannya masing-masing (kan. 275, §2). Paus Benediktus XVI, ketika masih memimpin Kongregasi Ajaran Iman, menegaskan bahwa keterlibatan di bidang politik adalah tugas khas kaum awam. Kaum awam tidak pernah boleh dihalangi atau diasingkan dari partisipasi aktif dan langsung dalam kehidupan politik suatu bangsa, dalam kerja sama dengan semua warga negara yang lain, sebagaimana juga tidak bisa diasingkan dari berbagai aktivitas di bidang ekonomi, sosial, legislatif, administratif, dan kultural, demi menumbuhkembangkan bonum commune secara organik dan institusional. Bonum commune itu mencakup promosi dan pemeliharaan tatanan publik dan perdamaian, kebebasan dan kesamaan

${ }^{35}$ Konsili Vatikan II, Gaudium et Spes, 559.

${ }^{36}$ Konsili Vatikan II, Apostolicam Actuositatem, 349. 
atau kesetaraan, hormat terhadap hidup manusia dan lingkungan hidup, keadilan, dan solidaritas, dan sebagainya. ${ }^{37}$

Selanjutnya, menjadi tugas hierarki Gereja untuk mendorong kegiatan kaum awam yang khas itu dengan menunjukkan prinsip-prinsip berpolitik yang benar dan memberikan bantuan rohani. Untuk itu, para Uskup hendaknya memberikan imam pendamping bagi kaum awam yang terlibat aktif dalam perpolitikan, agar dalam berpolitik kaum awam sungguhsungguh dibimbing oleh hati-nurani kristiani, mengambil pilihan-pilihan politis yang tidak mengkhianati tuntutan-tuntutan etis fundamental demi kebaikan umum masyarakat luas. Ini karena tuntutan etis fundamental berakar dalam martabat pribadi manusia dan merupakan bagian dari hukum moral kodrati. ${ }^{38}$

\section{Kontribusi bagi Kepemimpinan Religius Para Pemimpin Ormas Keagamaan di Indonesia}

Beberapa pemimpin ormas keagamaan Islam di DKI Jakarta dan sekitarnya, pada trimester pertama 2017 sebenarnya telah menerapkan leadership yang efektif dan mengagumkan dalam mengompakkan secara internal dan eksternal segenap anggota kelompoknya, untuk menghadapi isu penodaan agama Islam oleh seorang calon pilgub DKI Jakarta. Mereka tidak ingin si penoda agama itu kembali memimpin ibukota Jakarta untuk lima tahun lagi. Karena itu, mereka ingin agar ia diadili dan dihukum, dan sekaligus gagal dalam pilkada gubernur Jakarta. Fakta menunjukkan bahwa para pemimpin ormas keagamaan itu berhasil mengkonsolidasi tidak hanya kelompoknya saja, melainkan juga ormas-ormas lain yang menganut nilai-nilai keagamaan yang sama. Menurut teori-teori leadership, mereka berhasil menerapkan leadership as the exercise of influence. Artinya, para pemimpin ormas keagamaan itu menggunakan kepemimpinannya untuk melancarkan sebuah pengaruh, lewat pidato, sikap dan perilaku yang jelas,

${ }^{37}$ Kongregasi Ajaran Iman, Nota Doktrinal L'impegno del cristiano, 24 November 2002, dalam Enchiridion Vaticanum, Vol. 21, Documenti Ufficiali della Santa Sede 2002, ed. Erminio Lora (Bologna: Dehoniano, 2005), 1023-24.

${ }^{38}$ Konsili Vatikan II, Apostolicam Actuositatem, 370; Kongregasi Ajaran Iman, L'impegno del Cristiano, 1030. 
agar segenap anggota organisasi memiliki sikap dan perilaku yang sama, serta bersama-sama menjalankan aksi tertentu untuk mencapai satu target yang sama. ${ }^{39}$ Selain itu, mereka berhasil menjalankan leadership as a form of persuasion. Artinya, mereka menggerakkan seluruh anggota kelompoknya untuk suatu aksi bersama, dengan menggunakan persuasi dan inspirasi, yang diungkapkan dalam bentuk ajakan-ajakan yang sangat emosional. Model kepemimpinan seperti itu biasanya memang digunakan dalam dunia politik, dan dalam menghadapi perkara-perkara sosial-keagamaan. ${ }^{40}$

Sebenarnya tidak ada yang salah dalam cara memimpin kelompok seperti di atas. Namun, jika kepemimpinan itu ternyata menimbulkan dampak negatif berkepanjangan terhadap kehidupan bersama yang damai antar warga masyarakat majemuk hingga mengancam kesatuan dan persatuan bangsa, maka ada kekurangan yang berat dan serius di sana. Persoalannya tentu tidak terletak pada organisasi internal kelompok, melainkan pada bagaimana pemimpin religius mampu melihat dan memperkenalkan perspektif dan paradigma baru kepada segenap anggota kelompok atau bawahannya, yang tadinya terkungkung pada cara pandang yang sempit, sektarian, ekstrim, dan intoleran. Studi komparatif dengan melihat gaya kepemimpinan para pemuka agama Katolik, khususnya Paus Benediktus XV dan Yohanes XXIII, menunjukkan unsur-unsur yang perlu ditambahkan pada model kepemimpinan para pimpinan ormas keagamaan tersebut.

Unsur baru itu bisa dirumuskan secara negatif sebagai berikut. Dalam situasi konflik atau potensi konflik horisontal di antara kelompokkelompok masyarakat, para pemimpin ormas keagamaan tidak boleh ikut terkooptasi dan menjadi sektarian, partisan atau parsialistik dengan membela kepentingan kelompoknya sendiri atau kelompok-kelompok lain yang memiliki identitas dan sentimen keagamaan yang sama, untuk menghadapi dan memusuhi kelompok agama yang lain. Kalau tidak, pemuka agama bukannya mendamaikan dan mempersatukan warga

39 Bernard M. Bass, ed., Stogdill's Handbook of Leadership: A Survey of Theory and Research (New York: Free Press; London: Collier Macmillan, 1981), 9-10.

${ }^{40}$ Bass, Stogdill's Handbook of Leadership, 10-11. 
masyarakat, melainkan justru memecah-belah berdasarkan sentimen keagamaan, alias mengalihkan dan mengkanalisasi konflik dan perpecahan, yang sebelumnya barangkali disebabkan oleh faktor-faktor non-agama, menjadi konflik atas dasar perbedaan agama atau keyakinan religius. Sejarah membuktikan bahwa konflik atas dasar sentimen keagamaan adalah yang paling panas, paling mengerikan, dan sangat irasional. Konflik itu tidak hanya menimbulkan banyak korban jiwa, melainkan juga peradaban dan persaudaraan insani, serta pendangkalan paham dan praktik keimanan yang autentik dari warga masyarakat.

Bila dirumuskan secara positif, dalam situasi konflik berdasarkan primodialisme SARA pemimpin ormas keagamaan harus memiliki dan menunjukkan kepada para anggota atau bawahannya sebuah kecerdasan spiritual, yakni dengan mengajak keluar dari dirinya sendiri, mengadopsi prinsip-prinsip dan nilai-nilai universal yang mampu mendekatkan dan bahkan menyatukan kelompoknya dengan kelompok-kelompok lain yang berbeda agama atau keyakinan religius, demi kebaikan umum, keadilan, persaudaraan universal, penegakan hak asasi manusia, khususnya kebebasan agama dan beragama, yang merupakan cita-cita bersama masyarakat plural. Tidaklah sulit menemukan prinsip-prinsip dan nilainilai universal itu dalam ajaran agama masing-masing. Agama Islam sendiri sebenarnya merupakan agama rahmatan lil'alamin, rahmat bagi seluruh alam semesta. Prinsip dan nilai tersebut mestinya mendorong para pemimpin ormas keagamaan Islam untuk mengambil posisi berdialog dengan semua unsur alam, khususnya sesama manusia dari berbagai suku, agama dan keyakinan religius. Keragaman merupakan rahmat dan anugerah Allah yang Mahaesa, dan sejauh berasal dari keesaan Allah keragaman akan mengantar kepada kesatuan dan persatuan. Dengan demikian, kebhinnekaan bukanlah musuh yang harus diperangi, melainkan menjadi alasan untuk bersyukur dan memuji Tuhan Allah yang Maha Esa (celebration of diversity). 


\section{Penutup}

Sebagai negara kesatuan yang terdiri dari aneka ragam suku, agama, ras, dan golongan, Indonesia selalu berada dalam resiko keterpecahan, jika kesatuan dalam keragaman ini tidak dirawat dengan baik dan dihidupi dengan penuh syukur. Posisi dan peran pemuka agama dan pemimpin ormas keagamaan sangat penting dan strategis dalam persoalan ini. Ketika muncul konflik atau potensi konflik sosial yang mengandung unsur primordial SARA, pemuka agama dan pemimpin ormas keagamaan tidak boleh jatuh kepada sektarianisme, ekstremisme, dan sikap partisan, yang semakin mempertajam atau memperparah konflik horisontal antar warga. Sebaliknya, para pemuka agama dan pemimpin ormas keagamaan harus segera awas dan mawas diri terhadap bahaya yang mengancam kehidupan bersama. Mereka harus menunjukkan kecerdasan spiritual dalam melaksanakan kepemimpinan mereka terhadap para anggota atau bawahannya. Kecerdasan spiritual itu berupa kemampuan dan kerelaan untuk keluar dari diri sendiri, mengatasi kesempitan wawasan diri, mengadopsi kepentingan yang lebih luas daripada kepentingan organisasi atau kelompok agamanya. Dengan meninggalkan dan menanggalkan kepentingan sempit dan sepihak golongannya, mereka hendaknya menerapkan rasionalitas dan moralitas yang diterima umum, memperjuangkan prinsip-prinsip dan nilai-nilai yang di-share oleh semua orang dari semua golongan, yakni bonum commune, keadilan, hak asasi manusia, peaceful co-habitation masyarakat majemuk. Jika terjadi pelanggaran terhadap nilai universal itu, bolehlah mereka memperjuangkan penegakan hukum, tidak hanya jika pelanggaran itu merugikan kelompoknya sendiri, melainkan juga ketika merugikan orang dari luar kelompoknya. Meski demikian, dalam menuntut penegakan hukum mereka tetap harus menjunjung setinggi-tingginya damai dan kerukunan di antara warga masyarakat. 


\section{Daftar Pustaka}

Allegri, Renzo. Il Papa Buono: La Storia di Giovanni XXIII. Milano: Oscar Mondadori, 2000.

Bass, Bernard M, ed. Stogdill's Handbook of Leadership: A Survey of Theory and Research. New York: Free Press; London: Collier Macmillan, 1981.

Beal, John P., James A. Coriden, dan Thomas J. Green, eds. New Commentary on the Code of Canon Law. New York: Paulist Press, 2000.

Benediktus XV. Ensiklik Ad beatissimi Apostolorum Principis, 1 November 1914. Dalam Enchiridion delle Encicliche, Vol. 4, Pio X e Benedetto XV (1903-1922), diedit oleh Erminio Lora dan Rita Simionati, 464-95. Bologna: Dehoniano, 1998.

Caparros, Ernest, Michel Thériault, dan Jean Thorn, eds. Code of Canon Law Annotated. Montréal: Wilson\&Lafleur, 1993.

Kelly, John N.D. Grande Dirionario Illustrato dei Papi, diterjemahkan oleh Antonella Riccio. Casale Monferrato: Piemme, 1995.

Kongregasi Ajaran Iman, Nota Doktrinal L'impegno del Cristiano. 24 November 2002. Dalam Enchiridion Vaticanum, vol. 21, Documenti Ufficiali della Santa Sede 2002, diedit oleh Erminio Lora, 1022-37. Bologna: Dehoniano, 2005.

Konsili Vatikan II. Dekret Apostolicam Actuositatem. Dalam Dokumen Konsili Vatikan II, diterjemahkan oleh Robertus Hardawiryana, 339-80. Jakarta: Dokpen KWI / Obor, 1993.

. Dekret Presbyterorum Ordinis. Dalam Dokumen Konsili Vatikan II, diterjemahkan oleh Robertus Hardawiryana, 459-508. Jakarta: Dokpen KWI / Obor, 1993. . Konstitusi Pastoral Gaudium et Spes. Dalam Dokumen Konsili Vatikan II, diterjemahkan oleh Ro-bertus Hardawiryana, 509-637. Jakarta: Dokpen KWI / Obor, 1993.

Lora, Erminio, dan Rita Simionati, eds. Enchiridion delle Encicliche, vol. 4, Pio Xe Benedetto XV (1903-1922). Bologna: Dehoniano, 1998. 
Marzoa, Angel, Jorge Miras, dan Rafael Rodríguez-Ocaña, eds. Exegetical Commentary on the Code of Canon Law, vol. II/1. Canada / Chicago: Wilson\&Lafleur / Midwest Theological Forum, 2004.

Sinode Para Uskup. Convenientes ex Universo. 30 November 1971. Dalam Enchiridion Vaticanum, vol. 4, Documenti Ufficiali della Santa Sede 1971 1973, diedit oleh Erminio Lora, 800-39. Bologna: Dehoniano, 1978. . Ultimis Temporibus. 30 November 1971. Dalam Enchiridion Vaticanum, vol. 4, Documenti Ufficiali della Santa Sede 1971-1973, diedit oleh Erminio Lora, 750-99. Bologna: Dehoniano, 1978.

Tjatur Raharso, Alphonsus. Pernak-Pernik Ajaran dan Keutamaan San Giovanni XXIII. Malang: Widya Sasana Publication, 2014.

Yohanes XXIII. Journal of a Soul, diterjemahkan oleh Dorothy White. London: Geoffrey Chapman, 2000. Ensiklik Pacem in Terris. 11 April 1963. Dalam Enchiridion delle Encicliche, Vol. 7, Giovanni XXIII e Paolo VI (1958-1978), diedit oleh Erminio Lora dan Rita Simionati, 380-469. Bologna: Dehoniano, 1994. 